\title{
State of Play: Eight Decades of Surgery for Esophageal Atresia
}

\author{
Julia Zimmer ${ }^{1}$ Simon Eaton ${ }^{2}$ Louise E. Murchison ${ }^{2}$ \\ Carmen Dingemann ${ }^{1}$ \\ ${ }^{1}$ Department of Pediatric Surgery, Hannover Medical School, \\ Hannover, Germany \\ 2 Department of Pediatric Surgery, University College London, \\ Institute of Child Health, London, United Kingdom \\ 3 Stem Cells and Regenerative Medicine, DBC, UCL Institute of Child \\ Health and Great Ormond Street Hospital, London, United Kingdom \\ Eur J Pediatr Surg 2019;29:39-48.
}

Paolo De Coppi ${ }^{3}$ Benno M. Ure ${ }^{1}$

\begin{abstract}
Address for correspondence Carmen Dingemann, MD, PhD, Department of Pediatric Surgery, Hannover Medical School, Carl-Neuberg-Straße 1, 30625 Hannover, Germany (e-mail: dingemann.carmen@mh-hannover.de).
\end{abstract}

Keywords

- esophageal atresia

- outcome

- surgical techniques

- mortality rate

- long-term morbidity
Aim Surgical expertise and advances in technical equipment and perioperative management have led to enormous progress in survival and morbidity of patients with esophageal atresia (EA) in the last decades. We aimed to analyze the available literature on surgical outcome of EA for the past 80 years.

Materials and Methods A PubMed literature search was conducted for the years 1944 to 2017 using the keywords "esophageal/oesophageal atresia," "outcome," "experience," "management," and "follow-up/follow up.” Reports on long-gap EA only, nonEnglish articles, case reports, and reviews without original patient data were excluded. We focused on mortality and rates of recurrent fistula, leakage, and stricture.

Results Literature search identified 747 articles, 118 manuscripts met the inclusion criteria. The first open end-to-end anastomosis and fistula ligation was reported in 1941. Thoracoscopic fistula ligation and primary anastomosis was performed first in 2000. Reported mortality rate decreased from 100\% before 1941 to $54 \%$ in 1950 to $1959,28 \%$ in 1970 to $1979,16 \%$ in 1990 to 1999 , and $9 \%$ nowadays. Rates of recurrent fistula varied over time between 4 and $9 \%$. Leakage rate remained stable between 11 and $16 \%$. However, stricture rate increased from 25 to $38 \%$.

Conclusion Including a full range of articles reflecting the heterogeneity of EA, mortality rate significantly decreased during the course of 80 years. Along with the decrease in mortality, there is a shift to the importance of major postoperative complications and long-term morbidity regardless of surgical technique.

\section{Introduction}

Advances in surgical expertise, technical equipment as well as anesthetic and neonatal intensive care management, have contributed to decreased mortality and morbidity rates of patient with esophageal atresia (EA) in the last decades. ${ }^{1-3}$

Before gradual implementation of surgical management, the mortality rate of EA patients was $100 \%$. The first survivors with the condition were independently reported by Leven and Ladd in 1939, who managed their cases with a staged approach consisting of initial gastrostomy, subsequent fistula ligation or division with cervical esophagostomy, and finally creation of an antethoracic skin tube conduit from the esophagostomy to the gastrostomy. ${ }^{4-7}$ The first successful open end-to-end anastomosis and fistula ligation was reported in 1941 by Haight and Towsley. ${ }^{8}$ At a later time, Haight revised his technique from a left extrapleural approach with single-layer anastomosis to two-layer anastomosis and a right extrapleural approach. ${ }^{4}$ Many of Haight's initial techniques still guide our current management of neonates born with EA. ${ }^{4}$ received

May 15, 2018

accepted

June 27, 2018

published online

August 15, 2018 (c) 2019 Georg Thieme Verlag KG Stuttgart · New York
DOI https://doi.org/

10.1055/s-0038-1668150. ISSN 0939-7248. 
Another milestone in EA surgery was achieved with the introduction of minimal invasive surgery. In 1999, the first successful thoracoscopic repair of a pure EA was performed. ${ }^{9}$ One year later, Rothenberg reported the first thoracoscopic fistula ligation and primary anastomosis. ${ }^{10}$ Since then, minimal invasive EA repair is deployed in increasing numbers worldwide. $^{11}$

This report aims to elucidate and compare the outcome development of EA throughout the decades since the first end-to-end anastomosis to modern era. Besides mortality rates, we focused on common and severe postoperative complications after EA repair, such as occurrence of recurrent fistula, anastomotic leakage, and stricture.

\section{Materials and Methods}

In January 2018, a PubMed literature search was conducted for the years 1944 to 2017 using different combinations of the following keywords: "esophageal/oesophageal atresia," "outcome," "experience," "management," and "follow-up/ follow up." Additionally, reference lists of included papers were screened manually for further studies. Duplicates were deleted.

\section{Selection Criteria and Data Extraction}

Relevant articles were reviewed by title, abstract, and keywords, and full-text of selected articles were assessed by one of the authors (J.Z.). Only articles in English language were considered. Reports on long-gap EA only, case reports, and reviews without original patient data were excluded. We focused on mortality and rates of recurrent fistula, leakage, and stricture. The data were standardized extracted into an electronic database, containing the characteristics of the study (authors, publication year, time frame of the study, number of patients, age/mean follow-up time, mortality rate, and percentage of patients with recurrent fistula, leakage, and stricture).

\section{Statistical Analysis}

Microsoft Excel was used for data analysis. The percentage of patients with recurrent fistula, leakage, and stricture as well as the percentage of patients who died was compared between the different decades.

\section{Results}

A total of 747 articles were identified through literature search, of which 118 manuscripts met the inclusion criteria ( $>$ Fig. 1). Included articles and their reported outcomes are shown in -Table 1. An overview of the included study types is given in -Table 2. All except for seven were retrospective studies. ${ }^{3,12-17}$ One was a randomized controlled trial as reported by Upadhyaya et al. ${ }^{18}$ It is notable that some reports comprise outcome data of several decades, which were matched to the related period.
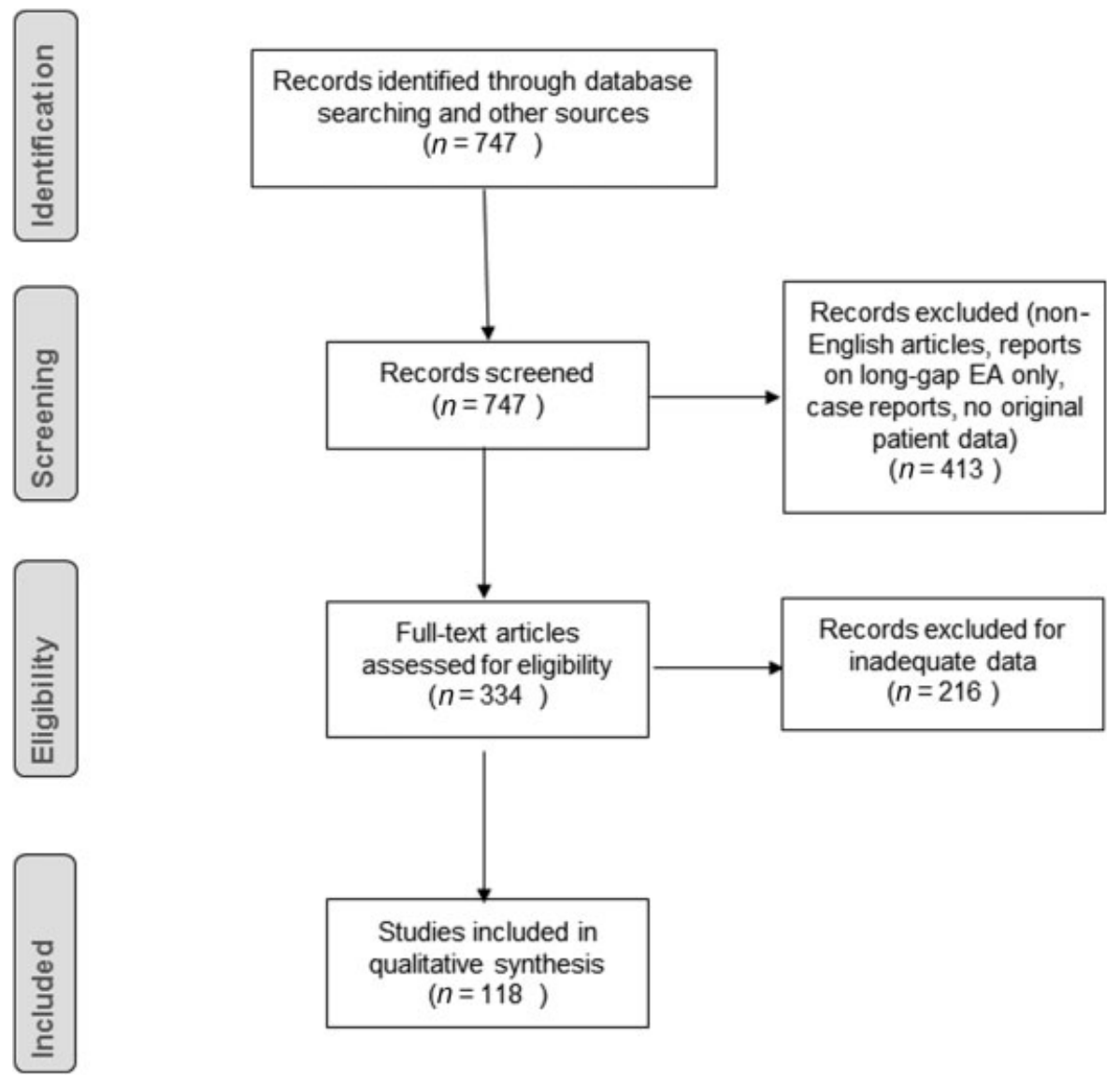

Studies included in

qualitative synthesis $(n=118)$

Fig. 1 PRISMA flow chart for data extraction. EA, esophageal atresia; PRISMA, Preferred Reporting Items for Systematic Reviews and MetaAnalyses. 
Table 1 Included articles and their characteristics for this study (chronological order)

\begin{tabular}{|c|c|c|c|c|c|c|c|}
\hline Author and year & Study period & Study type & $\begin{array}{l}\text { No. of } \\
\text { patients }\end{array}$ & $\begin{array}{l}\text { Anastomotic } \\
\text { leak }\end{array}$ & $\begin{array}{l}\text { Recurrent } \\
\text { fistula }\end{array}$ & $\begin{array}{l}\text { Stricture } \\
\text { rate }\end{array}$ & Mortality \\
\hline Donoso and Lilja $2017^{53}$ & $1994-2013$ & Retrospective & 129 & Yes & No & Yes & Yes \\
\hline Tröbs et al $2017^{54}$ & $2006-2013$ & Retrospective & 24 & $N / R$ & $N / R$ & $N / R$ & Yes \\
\hline Long et al $2017^{15}$ & $2008-2009$ & Prospective & 21 & Yes & No & Yes & $N / R$ \\
\hline Acher et al $2016^{17}$ & Not specified & Prospective & 445 & Yes & $\mathrm{N} / \mathrm{R}$ & Yes & $\mathrm{N} / \mathrm{R}$ \\
\hline Bakal et al $2016^{55}$ & $1996-2011$ & Retrospective & 51 & Yes & $N / R$ & Yes & Yes \\
\hline Bradshaw et al $2016^{56}$ & $2004-2013$ & Retrospective & 58 & Yes & $\mathrm{N} / \mathrm{R}$ & Yes & Yes \\
\hline Dingemann et al $2016^{25}$ & $2007-2012$ & Retrospective & 75 & Yes & Yes & Yes & No \\
\hline Donoso et al $2016^{57}$ & $1994-2013$ & Retrospective & 129 & Yes & Yes & Yes & Yes \\
\hline Hannon et al $2016^{27}$ & 1993-2015 & Retrospective & 9 & $N / R$ & Yes & $N / R$ & Yes \\
\hline Hartley et al $2016^{58}$ & $1996-2014$ & Retrospective & 120 & Yes & $N / R$ & $N / R$ & Yes \\
\hline Malakounides et al $2016^{35}$ & $2001-2011$ & Retrospective & 200 & $\mathrm{~N} / \mathrm{R}$ & $\mathrm{N} / \mathrm{R}$ & $\mathrm{N} / \mathrm{R}$ & Yes \\
\hline Okata et al $2016^{59}$ & 2000-2015 & Retrospective & 28 & Yes & No & Yes & $\mathrm{N} / \mathrm{R}$ \\
\hline Tong et al $2016^{60}$ & $2008-2014$ & Retrospective & 35 & Yes & $\mathrm{N} / \mathrm{R}$ & $\mathrm{N} / \mathrm{R}$ & $\mathrm{N} / \mathrm{R}$ \\
\hline Okuyama et al $2015^{21}$ & Not specified & Retrospective & 58 & Yes & Yes & Yes & Yes \\
\hline Pini Prato et al $2015^{14}$ & $2011-2013$ & Prospective & 146 & Yes & Yes & Yes & Yes \\
\hline Uygun et al $2015^{61}$ & 2009-2013 & Retrospective & 6 & Yes & $\mathrm{N} / \mathrm{R}$ & Yes & Yes \\
\hline Allin et al $2014^{12}$ & $2008-2009$ & Prospective & 151 & Yes & Yes & Yes & Yes \\
\hline Dunkley et al $2014^{52}$ & 1990-2007 & Retrospective & 66 & Yes & Yes & Yes & Yes \\
\hline Fallon et al $2014^{62}$ & $2002-2012$ & Retrospective & 91 & Yes & Yes & Yes & Yes \\
\hline Lee et al $2014^{63}$ & $2008-2013$ & Retrospective & 23 & Yes & Yes & Yes & $N / R$ \\
\hline Schneider et al $2014^{13}$ & $2008-2009$ & Prospective & 307 & Yes & Yes & Yes & Yes \\
\hline Sulkowski et al $2014^{48}$ & 1999-2012 & Retrospective & 3479 & $N / R$ & Yes & $N / R$ & Yes \\
\hline Wang et al $2014^{1}$ & 2000-2009 & Retrospective & 4168 & $\mathrm{~N} / \mathrm{R}$ & $\mathrm{N} / \mathrm{R}$ & $\mathrm{N} / \mathrm{R}$ & Yes \\
\hline Yamato et al $2014^{29}$ & $2001-2012$ & Retrospective & 26 & Yes & Yes & Yes & No \\
\hline Burge et al $2013^{16}$ & 2008-2009 & Prospective & 151 & Yes & $\mathrm{N} / \mathrm{R}$ & $\mathrm{N} / \mathrm{R}$ & Yes \\
\hline Dingemann et al $2013^{26}$ & $2001-2011$ & Retrospective & 44 & Yes & Yes & No & No \\
\hline Koivusalo et al $2013^{37}$ & $1991-2001$ & Retrospective & 130 & Yes & Yes & Yes & Yes \\
\hline Niramis et al $2013^{64}$ & $2003-2010$ & Retrospective & 132 & Yes & Yes & Yes & Yes \\
\hline Rothenberg $2013^{24}$ & $2000-2012$ & Retrospective & 61 & Yes & No & Yes & No \\
\hline Sfeir et al $2013^{3}$ & 2008-2009 & Prospective & 307 & $\mathrm{~N} / \mathrm{R}$ & Yes & Yes & Yes \\
\hline Sfeir et al $2013^{65}$ & 2008-2009 & Retrospective & 307 & $\mathrm{~N} / \mathrm{R}$ & $\mathrm{N} / \mathrm{R}$ & $\mathrm{N} / \mathrm{R}$ & Yes \\
\hline Huang et al $2012^{46}$ & 2007-2012 & Retrospective & 33 & Yes & Yes & Yes & Yes \\
\hline Jawaid et al $2012^{66}$ & 1999-2009 & Retrospective & 119 & Yes & Yes & Yes & Yes \\
\hline Oddsberg et al $2012^{47}$ & 1964-2007 & Retrospective & 1126 & $N / R$ & $N / R$ & $N / R$ & Yes \\
\hline Rothenberg $2012^{30}$ & $N / R$ & Retrospective & 49 & Yes & No & Yes & No \\
\hline Spoel et al $2012^{50}$ & 2005-2009 & Retrospective & 37 & $N / R$ & $N / R$ & Yes & $N / R$ \\
\hline Burford et al $2011^{67}$ & 1993-2008 & Retrospective & 72 & Yes & Yes & Yes & $\mathrm{N} / \mathrm{R}$ \\
\hline Sistonen et al $2011^{68}$ & 1947-1985 & Retrospective & 101 & Yes & Yes & Yes & Yes \\
\hline Szavay et al $2011^{22}$ & $2002-2010$ & Retrospective & 68 & Yes & $\mathrm{N} / \mathrm{R}$ & $\mathrm{N} / \mathrm{R}$ & No \\
\hline Zhao et al $2011^{69}$ & $2000-2009$ & Retrospective & 85 & Yes & $N / R$ & Yes & $N / R$ \\
\hline Jong et al $2010^{70}$ & $2000-2006$ & Retrospective & 59 & Yes & Yes & Yes & Yes \\
\hline Lacher et al $2010^{36}$ & 1988-2009 & Retrospective & 111 & Yes & Yes & Yes & Yes \\
\hline Serhal et al $2010^{71}$ & $2000-2005$ & Retrospective & 62 & Yes & $N / R$ & $\mathrm{~N} / \mathrm{R}$ & $\mathrm{N} / \mathrm{R}$ \\
\hline
\end{tabular}


42 Eight Decades of Surgery for Esophageal Atresia Zimmer et al.

Table 1 (Continued)

\begin{tabular}{|c|c|c|c|c|c|c|c|}
\hline Author and year & Study period & Study type & $\begin{array}{l}\text { No. of } \\
\text { patients }\end{array}$ & $\begin{array}{l}\text { Anastomotic } \\
\text { leak }\end{array}$ & $\begin{array}{l}\text { Recurrent } \\
\text { fistula }\end{array}$ & $\begin{array}{l}\text { Stricture } \\
\text { rate }\end{array}$ & Mortality \\
\hline MacKinlay $2009^{72}$ & $N / R$ & Retrospective & 36 & Yes & Yes & Yes & Yes \\
\hline Patkowsk et al $2009^{73}$ & $2005-2008$ & Retrospective & 23 & Yes & No & Yes & Yes \\
\hline Petrosyan et al $2009^{2}$ & $1987-2009$ & Retrospective & 25 & Yes & No & Yes & Yes \\
\hline Tandon et al $2009^{74}$ & $2007-2008$ & Retrospective & 98 & Yes & $N / R$ & $N / R$ & Yes \\
\hline Lilja et al. $2008^{38}$ & $1986-2005$ & Retrospective & 147 & Yes & Yes & Yes & Yes \\
\hline Lugo et al $2008^{23}$ & $2000-2006$ & Retrospective & 33 & Yes & $N / R$ & Yes & No \\
\hline Sri Paran et al $2007^{75}$ & $1977-2004$ & Retrospective & 26 & $N / R$ & $N / R$ & Yes & Yes \\
\hline Upadhyaya et al $2007^{18}$ & $2004-2006$ & RCT & 50 & Yes & $N / R$ & Yes & Yes \\
\hline $\begin{array}{l}\text { van der Zee and Bax } \\
2007^{76}\end{array}$ & $2000-2006$ & Retrospective & 51 & Yes & Yes & Yes & Yes \\
\hline Al-Salem et al $2006^{33}$ & 1989-2004 & Retrospective & 94 & Yes & Yes & Yes & Yes \\
\hline Sugito et al $2006^{34}$ & $1975-2003$ & Retrospective & 24 & Yes & Yes & Yes & Yes \\
\hline Uchida et al $2006^{77}$ & $1979-2003$ & Retrospective & 42 & Yes & Yes & Yes & Yes \\
\hline Yang et al $2006^{31}$ & $1994-2003$ & Retrospective & 15 & Yes & No & Yes & Yes \\
\hline Al-Malki et al $2005^{78}$ & $1990-2000$ & Retrospective & 101 & $N / R$ & $N / R$ & $N / R$ & Yes \\
\hline Holcomb et al $2005^{39}$ & $N / R$ & Retrospective & 104 & Yes & Yes & Yes & $N / R$ \\
\hline Calisti et al $2004^{79}$ & 1999-2002 & Retrospective & 75 & Yes & Yes & Yes & Yes \\
\hline Deurloo et al $2004^{80}$ & 1982-2002 & Retrospective & 197 & Yes & Yes & $N / R$ & Yes \\
\hline Orford et al $2004^{81}$ & $1970-2000$ & Retrospective & 152 & Yes & $N / R$ & Yes & Yes \\
\hline Tonz et al $2004^{82}$ & 1973-1999 & Retrospective & 104 & Yes & Yes & Yes & Yes \\
\hline Touloukian, Seashore ${ }^{83}$ & $1968-2003$ & Retrospective & 143 & Yes & Yes & Yes & Yes \\
\hline Konkin et al $2003^{84}$ & $1984-2000$ & Retrospective & 144 & Yes & Yes & Yes & Yes \\
\hline Little et al $2003^{43}$ & 1972-1990 & Retrospective & 69 & Yes & $N / R$ & Yes & $N / R$ \\
\hline $\begin{array}{l}\text { van der Zee and Bax } \\
2003^{85}\end{array}$ & 2002 & Retrospective & 13 & Yes & $N / R$ & Yes & $N / R$ \\
\hline Deurloo et al $2002^{86}$ & $1947-2000$ & Retrospective & 371 & Yes & Yes & Yes & Yes \\
\hline Sharma et al $2000^{32}$ & 1972-1996 & Retrospective & 585 & Yes & Yes & Yes & Yes \\
\hline Sparey et al $2000^{87}$ & 1985-1997 & Retrospective & 120 & $N / R$ & $N / R$ & Yes & Yes \\
\hline Nawaz et al $1998^{88}$ & 1981-1996 & Retrospective & 41 & Yes & No & Yes & Yes \\
\hline Somppi et al $1998^{89}$ & $1963-1993$ & Retrospective & 60 & $N / R$ & $N / R$ & $N / R$ & Yes \\
\hline Okada et al 1997 & 1957-1995 & Retrospective & 159 & Yes & Yes & Yes & Yes \\
\hline Tsai et al $1997^{90}$ & 1957-1995 & Retrospective & 81 & Yes & $N / R$ & Yes & Yes \\
\hline Engum et al $1995^{91}$ & 1971-1993 & Retrospective & 227 & $N / R$ & Yes & Yes & Yes \\
\hline Rokitansky et al $1994^{92}$ & 1960-1991 & Retrospective & 309 & $N / R$ & $N / R$ & $N / R$ & Yes \\
\hline Spitz et al $1994^{28}$ & 1980-1992 & Retrospective & 372 & $N / R$ & $N / R$ & $N / R$ & Yes \\
\hline Alexander et al $1993^{93}$ & 1966-1986 & Retrospective & 25 & Yes & Yes & Yes & Yes \\
\hline Rokitansky et al $1993^{45}$ & 1975-1991 & Retrospective & 223 & Yes & Yes & Yes & Yes \\
\hline Touloukian $1992^{94}$ & $1968-1990$ & Retrospective & 68 & Yes & Yes & Yes & Yes \\
\hline Poenaru et al $1991^{95}$ & $1962-1988$ & Retrospective & 131 & Yes & Yes & Yes & Yes \\
\hline $\begin{array}{l}\text { McKinnon and Kosloske } \\
1990^{96}\end{array}$ & $1976-1989$ & Retrospective & 64 & Yes & Yes & Yes & Yes \\
\hline Adebo $1990^{97}$ & 1977-1987 & Retrospective & 11 & Yes & $N / R$ & Yes & Yes \\
\hline $\begin{array}{l}\text { Chittmittrapap et al } \\
1990^{98}\end{array}$ & 1980-1987 & Retrospective & 199 & Yes & Yes & Yes & $N / R$ \\
\hline
\end{tabular}


Table 1 (Continued)

\begin{tabular}{|c|c|c|c|c|c|c|c|}
\hline Author and year & Study period & Study type & $\begin{array}{l}\text { No. of } \\
\text { patients }\end{array}$ & $\begin{array}{l}\text { Anastomotic } \\
\text { leak }\end{array}$ & $\begin{array}{l}\text { Recurrent } \\
\text { fistula }\end{array}$ & $\begin{array}{l}\text { Stricture } \\
\text { rate }\end{array}$ & Mortality \\
\hline Randolph et al $1988^{99}$ & $1966-1988$ & Retrospective & 118 & Yes & $N / R$ & Yes & Yes \\
\hline Pohlsen et al $1988^{100}$ & $1980-1986$ & Retrospective & 70 & Yes & $\mathrm{N} / \mathrm{R}$ & $\mathrm{N} / \mathrm{R}$ & Yes \\
\hline Sillen et al $1988^{101}$ & 1967-1984 & Retrospective & 110 & Yes & $N / R$ & Yes & Yes \\
\hline Biller et al $1987^{102}$ & $1950-1960$ & Retrospective & 12 & No & $N / R$ & Yes & $N / R$ \\
\hline $\begin{array}{l}\text { Connolly and Guiney } \\
1987^{103}\end{array}$ & $1974-1983$ & Retrospective & 139 & Yes & Yes & Yes & Yes \\
\hline Spitz et al $1987^{104}$ & 1980-1985 & Retrospective & 148 & Yes & Yes & Yes & Yes \\
\hline Manning et al $1986^{4}$ & $1935-1985$ & Retrospective & 426 & Yes & Yes & Yes & Yes \\
\hline Bishop et al $1985^{105}$ & $1951-1983$ & Retrospective & 240 & Yes & Yes & Yes & Yes \\
\hline $\begin{array}{l}\text { Louhimo and Lindahl } \\
1983^{106}\end{array}$ & $1947-1978$ & Retrospective & 500 & Yes & Yes & Yes & Yes \\
\hline O’Neill et al $1982^{107}$ & $1971-1980$ & Retrospective & 53 & Yes & $N / R$ & Yes & Yes \\
\hline Lindahl et al $1982^{108}$ & 1949-1955 & Retrospective & 54 & Yes & Yes & $N / R$ & Yes \\
\hline Touloukian $1981^{109}$ & $1968-1979$ & Retrospective & 38 & Yes & Yes & Yes & Yes \\
\hline Atwell et al $1980^{110}$ & 1967-1976 & Retrospective & 6 & $N / R$ & $N / R$ & Yes & Yes \\
\hline Strodel et al $1979^{42}$ & $\mathrm{~N} / \mathrm{R}$ & Retrospective & 365 & Yes & Yes & Yes & Yes \\
\hline $\begin{array}{l}\text { Hrabovsky and Boles } \\
1978^{111}\end{array}$ & $1961-1973$ & Retrospective & 135 & Yes & $N / R$ & Yes & Yes \\
\hline $\begin{array}{l}\text { Fasting and Winther } \\
1978^{112}\end{array}$ & 1952-1976 & Retrospective & 86 & Yes & $N / R$ & Yes & Yes \\
\hline Pietsch et al $1978^{113}$ & 1962-1977 & Retrospective & 52 & Yes & Yes & Yes & Yes \\
\hline Exarhos et al1977 114 & $\mathrm{~N} / \mathrm{R}$ & Retrospective & 16 & $\mathrm{~N} / \mathrm{R}$ & $N / R$ & Yes & Yes \\
\hline Orringer et al $1977^{115}$ & $N / R$ & Retrospective & 22 & $N / R$ & $N / R$ & Yes & $N / R$ \\
\hline Ein and Themann $1973^{49}$ & 2,5 years & Retrospective & 38 & Yes & Yes & Yes & Yes \\
\hline Laks et al $1972^{116}$ & $1945-1955$ & Retrospective & 45 & $N / R$ & $N / R$ & Yes & $N / R$ \\
\hline Battersby et al $1971^{117}$ & 1940-1969 & Retrospective & 210 & $\mathrm{~N} / \mathrm{R}$ & $\mathrm{N} / \mathrm{R}$ & $\mathrm{N} / \mathrm{R}$ & Yes \\
\hline Ferguson et al $1970^{118}$ & 1954-1969 & Retrospective & 69 & $\mathrm{~N} / \mathrm{R}$ & $\mathrm{N} / \mathrm{R}$ & $\mathrm{N} / \mathrm{R}$ & Yes \\
\hline $\begin{array}{l}\text { Holden and Wooler } \\
1970^{119}\end{array}$ & 1939-1967 & Retrospective & 116 & Yes & $N / R$ & Yes & Yes \\
\hline Krishinger et al $1969^{120}$ & $1944-1968$ & Retrospective & 30 & Yes & Yes & Yes & Yes \\
\hline Romsdahl et al $1966^{121}$ & 1949-1965 & Retrospective & 34 & $N / R$ & Yes & Yes & Yes \\
\hline Wayson et al $1965^{41}$ & 1940-1965 & Retrospective & 89 & Yes & Yes & Yes & Yes \\
\hline Waterston et al $1962^{122}$ & $1946-1959$ & Retrospective & 218 & $\mathrm{~N} / \mathrm{R}$ & $N / R$ & $N / R$ & Yes \\
\hline Hays $1962^{123}$ & $1950-1960$ & Retrospective & 110 & $\mathrm{~N} / \mathrm{R}$ & $\mathrm{N} / \mathrm{R}$ & $\mathrm{N} / \mathrm{R}$ & Yes \\
\hline $\begin{array}{l}\text { Rehbein and Yanagiswa } \\
1958^{124}\end{array}$ & $1951-1958$ & Retrospective & 84 & Yes & Yes & Yes & Yes \\
\hline $\begin{array}{l}\text { Parish and Cummings } \\
1958^{5}\end{array}$ & $\mathrm{~N} / \mathrm{R}$ & Retrospective & 17 & $\mathrm{~N} / \mathrm{R}$ & $N / R$ & Yes & Yes \\
\hline Ashe and Seibold $1949^{125}$ & $\mathrm{~N} / \mathrm{R}$ & Retrospective & 8 & Yes & $\mathrm{N} / \mathrm{R}$ & Yes & Yes \\
\hline $\begin{array}{l}\text { Ladd and Swenson } \\
19947^{126}\end{array}$ & $1940-1946$ & Retrospective & 75 & $N / R$ & $N / R$ & $\mathrm{~N} / \mathrm{R}$ & Yes \\
\hline Daniel $1944^{127}$ & $1941-1944$ & Retrospective & 7 & $N / R$ & $N / R$ & $N / R$ & Yes \\
\hline Haight $1944^{128}$ & $1935-1944$ & Retrospective & 28 & $N / R$ & $N / R$ & $N / R$ & Yes \\
\hline
\end{tabular}

Abbreviations: N/R, mortality or morbidity not reported; No, no mortality or morbidity occurred during the study period; RCT, randomized controlled trial; Yes, rate for mortality or morbidity is mentioned in the paper.

Note: For reasons of clarity, this table gives only a brief overview of the recorded data of included papers. The extended table with staggered outcome regarding the different decades can be requested from the authors. 
Table 2 Overview of included study types (multiple selections possible)

\begin{tabular}{|l|l|}
\hline Study type & Number of studies \\
\hline Randomized controlled trials & 1 \\
\hline Prospective studies & 7 \\
\hline Retrospective studies & 110 \\
\hline Multicenter studies & 10 \\
\hline Single-center studies & 100 \\
\hline Comparative Studies & 7 \\
\hline
\end{tabular}

A total of 102 (86\%) of the included studies reported on mortality. Reported mortality rate after EA repair decreased markedly over time. It dropped from $100 \%$ in the presurgical era to $81 \%$ in the 1940 s and to $54 \%$ in the 1950 s. Further reduction followed in the next decades with $36 \%$ in 1960 to $1969,28 \%$ in 1970 to 1979 , and $16 \%$ in 1980 to 1989 and 1990 to 1999 . In the postmillennial era, mortality rate after EA repair decreased further to $12 \%$ in 2000 to 2009 , and in the current decade, it is $9 \%$ (-Fig. 2 ).

Reported rates of recurrent fistula varied over time between 4 and $9 \%$, and leakage rate varied between 11 and $16 \%$ (-Fig. 2). The number of studies reporting on recurrent fistula and leakage rate were 67 (56\%) and 89 (75\%), respectively, in this study.

Ninety-one (77\%) out of 118 included papers reported on stricture rate. Stricture rate showed a substantial increase in the last decade. Between 1940 and 2009, the reported rate varied between 25 and 31\%, whereas the average stricture rate was 38\% in 2010 to 2017 (-Fig. 2).
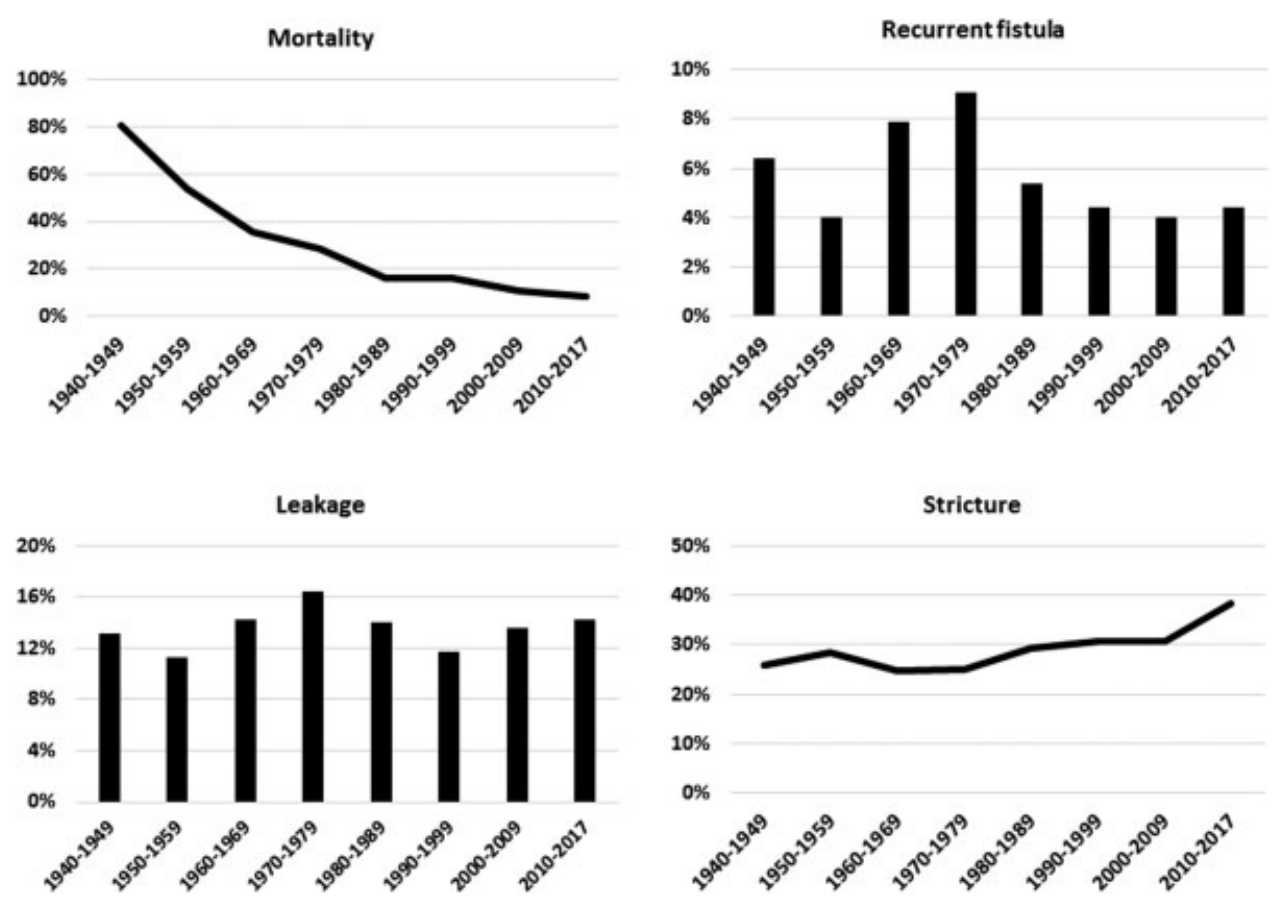

Fig. 2 Reported mortality rate decreased from $100 \%$ before 1941 to $54 \%$ in 1950 to 1959 , 28\% in 1970 to 1979 , $16 \%$ in 1990 to 1999 , and $9 \%$ nowadays. Rates of recurrent fistula varied over time between 4 and $9 \%$ and leakage rate varied between 11 and $16 \%$. However, stricture rate increased from 25 to $38 \%$. 
their study, all infants below $800 \mathrm{~g}$ body weight had poor outcome. ${ }^{27}$ In contrast, there is $95 \%$ expected survival in babies of more than $1500 \mathrm{~g}$ body weight, depending on their comorbidites. $^{27,28}$

Although several authors published a survival rate of $100 \%$ in their center, ${ }^{22-24,26,29,30}$ the overall mortality found in this study was between 9 and $11 \%$ in the last two decades. This is due to the fact that we also included studies with very-lowbirth-weight infants and articles from third world countries in this report. ${ }^{27,31-34}$ However, it has been suggested that birth weight is nowadays not an important factor as it was previously, although major cardiac anomalies are still of poor prognostic aspect. ${ }^{35}$

In our report, leakage rate remained stable over time between 11 and 16\%, suggesting that surgical variations do not have any substantial influence on this complication. Likewise, neither open nor thoracoscopic technique seems to markedly affect the rate of recurrent fistula. ${ }^{36-42}$ Although, there are minor variations between 4 and 9\% over time course, there was no further improvement since introduction of the minimal invasive technique. It remains elusive, why we observed a drop to $4 \%$ rate of recurrent fistula in the 1950 s compared with high rates up to $9 \%$ in the following two decades.

Surprisingly, we found that stricture rate after EA repair increased in the last decade. A recent survey admonishes that retrospective studies of EA may underestimate longterm esophageal complications, such as strictures. ${ }^{17}$ It is debatable, whether pediatric surgeons have become more aware of this complication during follow-up appointments over time and may therefore indicate endoscopic diagnostic including balloon dilatation or bougienage more generously. On the other hand, there is no uniform definition for "stricture" and indication of therapeutic interventions, which might explain the observed stricture rate variation between 4 and almost 90\%. Additionally, thoracoscopic technique and its associated learning curve might also affect anastomotic narrowing. Correspondingly, Rothenberg described stricture rates of almost $50 \%$ in their initial minimal invasive series, decreasing later to $20 \%{ }^{24}$ Furthermore, babies less than $1500 \mathrm{~g}$ of body weight have been found to have an increased risk of stricturing with primary EA repair. $^{2}$ In several long-term analyses, dysphagia and swallow difficulties have been shown to be common problems. ${ }^{36,43,44}$ However, they seem to occur mainly in the first years of life and become clinically less relevant thereafter as most children learn coping mechanisms over the years. ${ }^{43,44}$ Nonetheless, the continuously high complication rates demonstrate that close interdisciplinary longterm follow-up is more important than ever. It is crucial to detect and treat the complications accordingly, and patients born with EA must be assisted for transition to adult care by their pediatric surgeon.

Remarkably, only one randomized control trial ${ }^{18}$ and seven prospective studies ${ }^{3,12-17}$ could be included in this study. A limited number of multicenter studies $1,3,12,13,21,39,45-48$ reported on their experiences, whereas the majority presented single center data. Likewise, also comparative studies were rare. $^{22,23,29,49-52}$ Therefore, the current level of evidence in EA treatment is very low, and reference networks such as The European Reference Network on Rare inherited and congenital anomalies (ERNICA), which aims to assure quality treatment with high levels of evidence for EA in the future, are urgently needed.

The authors are aware of study limitations. A key point is the heterogeneity of included EA cases. No distinction was made between different types of EA (gap length, existence of a tracheoesophageal fistula). As we aimed to show the worldwide overall outcome of morbidity and mortality over time course, the articles were not extracted for surgical technique (open vs. minimal invasive, anastomotic technique, and primary vs. staged repair), birth weight/age, associated anomalies, time of follow-up, or country of origin (industrial states vs. third world countries). There is also a potential bias in study selection for the current manuscript. Amount of accessibility of papers from the early decades was restricted. Furthermore, there is a considerable variety of therapeutic regimen and treatment strategies among the different centers involved in EA treatment as well as the possibility of selection bias in the included studies themselves.

\section{Conclusion}

This article reflects the heterogeneity of EA, its patients, and its repair modalities during the course of 80 years. The worldwide mortality rate decreased from $100 \%$ in the presurgical era to a single-digit range in the last decade. Along with the decrease in mortality, there is a shift to the importance of major postoperative complications and long-term morbidity regardless of surgical technique. Therefore, close and regular follow-up of EA patients must be mandatory to assure health and normal development not only during childhood, but also for transition into adult care. Further studies, particularly prospective or randomized controlled trials, or at least consensus conferences, are needed to achieve higher levels of evidence and quality improvement for current therapeutic strategies for EA treatment.

Conflict of interest

None.

Acknowledgement

Paolo De Coppi wishes to acknowledge support from the National Institute for Health Research.

\section{References}

1 Wang B, Tashiro J, Allan BJ, et al. A nationwide analysis of clinical outcomes among newborns with esophageal atresia and tracheoesophageal fistulas in the United States. J Surg Res 2014;190 (02):604-612

2 Petrosyan M, Estrada J, Hunter C, et al. Esophageal atresia/ tracheoesophageal fistula in very low-birth-weight neonates: improved outcomes with staged repair. J Pediatr Surg 2009;44 (12):2278-2281

3 Sfeir R, Bonnard A, Khen-Dunlop N, et al. Esophageal atresia: data from a national cohort. J Pediatr Surg 2013;48(08):1664-1669 
4 Manning PB, Morgan RA, Coran AG, et al. Fifty years' experience with esophageal atresia and tracheoesophageal fistula. Beginning with Cameron Haight's first operation in 1935. Ann Surg 1986;204(04):446-453

5 Parish C, Cummins CF. Oesophageal atresia; experience in 17 cases, with notes on operative technique. BMJ 1958;1(5080):1140-1144

6 Ladd WE. The surgical treatment of esophageal atresia and tracheoesophageal fistulas. N Engl J Med 1944;230(21):625-637

7 Leven NL. Congenital atresia of esophagus with tracheoesophageal fistula: report of successful extrapleural ligation of fistulous communication and cervical esophagotomy. J Thorac Surg 1941; 10:648-657

8 Haight C, Towsley HA. Congenital atresia of the oesophagus with trachea-oesophageal fistula: Extrapleural ligation of fistula and end-to-end-anastomosis of oesophageal segments. Surg Gynecol Obstet 1943;76:672-688

9 Lobe TE, Rothenberg S, Waldschmidt J, Stroedter L. Thoracoscopic repair of esophageal atresia in an infant: a surgical first. Pediatric Endosurgery \& Innovative Techniques. 1999;3(03):141-148

10 Rothenberg SS. Thoracoscopic repair of a tracheoesophageal fistula in a newborn infant. Pediatric Endosurgery \& Innovative Techniques. 2000;4(04):289-294

11 Lal D, Miyano G, Juang D, Sharp NE, St Peter SD. Current patterns of practice and technique in the repair of esophageal atresia and tracheoesophageal fistula: an IPEG survey. J Laparoendosc Adv Surg Tech A 2013;23(07):635-638

12 Allin B, Knight M, Johnson P, Burge D; BAPS-CASS. Outcomes at one-year post anastomosis from a national cohort of infants with oesophageal atresia. PLoS One 2014;9(08):e106149

13 Schneider A, Blanc S, Bonnard A, et al. Results from the French National Esophageal Atresia register: one-year outcome. Orphanet J Rare Dis 2014;9:206

14 Pini Prato A, Carlucci M, Bagolan P, et al. A cross-sectional nationwide survey on esophageal atresia and tracheoesophageal fistula. J Pediatr Surg 2015;50(09):1441-1456

15 Long A-M, Tyraskis A, Allin B, Burge DM, Knight M. Oesophageal atresia with no distal tracheoesophageal fistula: management and outcomes from a population-based cohort. J Pediatr Surg 2017;52(02):226-230

16 Burge DM, Shah K, Spark P, et al; British Association of Paediatric Surgeons Congenital Anomalies Surveillance System (BAPS-CASS). Contemporary management and outcomes for infants born with oesophageal atresia. Br J Surg 2013;100 (04):515-521

17 Acher CW, Ostlie DJ, Leys CM, Struckmeyer S, Parker M, Nichol PF. Long-term outcomes of patients with tracheoesophageal fistula/ esophageal atresia: survey results from tracheoesophageal fistula/esophageal atresia online communities. Eur J Pediatr Surg 2016;26(06):476-480

18 Upadhyaya VD, Gangopadhyaya AN, Gopal SC, et al. Is ligation of azygos vein necessary in primary repair of tracheoesophageal fistula with esophageal atresia? Eur J Pediatr Surg 2007;17(04): 236-240

19 Cloud DT. Anastomotic technic in esophageal atresia. J Pediatr Surg 1968;3(05):561-564

20 Davenport M, Rothenberg SS, Crabbe DCG, Wulkan ML. The great debate: open or thoracoscopic repair for oesophageal atresia or diaphragmatic hernia. J Pediatr Surg 2015;50(02):240-246

21 Okuyama H, Koga H, Ishimaru T, et al. Current practice and outcomes of thoracoscopic esophageal atresia and tracheoesophageal fistula repair: a multi-institutional analysis in Japan. J Laparoendosc Adv Surg Tech A 2015;25(05):441-444

22 Szavay PO, Zundel S, Blumenstock G, et al. Perioperative outcome of patients with esophageal atresia and tracheo-esophageal fistula undergoing open versus thoracoscopic surgery. J Laparoendosc Adv Surg Tech A 2011;21(05):439-443

23 Lugo B, Malhotra A, Guner Y, Nguyen T, Ford H, Nguyen NX. Thoracoscopic versus open repair of tracheoesophageal fistula and esophageal atresia. J Laparoendosc Adv Surg Tech A 2008;18 (05):753-756

24 Rothenberg SS. Thoracoscopic repair of esophageal atresia and tracheoesophageal fistula in neonates, first decade's experience. Dis Esophagus 2013;26(04):359-364

25 Dingemann C, Dietrich J, Zeidler J, et al. Early complications after esophageal atresia repair: analysis of a German health insurance database covering a population of 8 million. Dis Esophagus 2016;29(07):780-786

26 Dingemann C, Zoeller C, Ure B. Thoracoscopic repair of oesophageal atresia: results of a selective approach. Eur J Pediatr Surg 2013;23(01):14-18

27 Hannon EJ, Billington J, Kiely EM, et al. Oesophageal atresia is correctable and survivable in infants less than $1 \mathrm{~kg}$. Pediatr Surg Int 2016;32(06):571-576

28 Spitz L, Kiely EM, Morecroft JA, Drake DP. Oesophageal atresia: at-risk groups for the 1990s. J Pediatr Surg 1994;29(06):723-725

29 Yamoto M, Urusihara N, Fukumoto K, et al. Thoracoscopic versus open repair of esophageal atresia with tracheoesophageal fistula at a single institution. Pediatr Surg Int 2014;30(09):883-887

30 Rothenberg SS. Thoracoscopic repair of esophageal atresia and tracheo-esophageal fistula in neonates: evolution of a technique. J Laparoendosc Adv Surg Tech A 2012;22(02):195-199

31 Yang C-F, Soong W-J, Jeng M-J, et al. Esophageal atresia with tracheoesophageal fistula: ten years of experience in an institute. J Chin Med Assoc 2006;69(07):317-321

32 Sharma AK, Shekhawat NS, Agrawal LD, Chaturvedi V, Kothari SK, Goel D. Esophageal atresia and tracheoesophageal fistula: a review of 25 years' experience. Pediatr Surg Int 2000;16(07):478-482

33 Al-Salem AH, Tayeb M, Khogair S, et al. Esophageal atresia with or without tracheoesophageal fistula: success and failure in 94 cases. Ann Saudi Med 2006;26(02):116-119

34 Sugito K, Koshinaga T, Hoshino M, et al. Study of 24 cases with congenital esophageal atresia: what are the risk factors? Pediatr Int 2006;48(06):616-621

35 Malakounides G, Lyon P, Cross K, et al. Esophageal atresia: improved outcome in high-risk groups revisited. Eur J Pediatr Surg 2016;26(03):227-231

36 Lacher M, Froehlich S, von Schweinitz D, Dietz HG. Early and long term outcome in children with esophageal atresia treated over the last 22 years. Klin Padiatr 2010;222(05):296-301

37 Koivusalo AI, Pakarinen MP, Rintala RJ. Modern outcomes of oesophageal atresia: single centre experience over the last twenty years. J Pediatr Surg 2013;48(02):297-303

38 Lilja HE, Wester T. Outcome in neonates with esophageal atresia treated over the last 20 years. Pediatr Surg Int 2008;24(05): 531-536

39 Holcomb GW III, Rothenberg SS, Bax KMA, et al. Thoracoscopic repair of esophageal atresia and tracheoesophageal fistula: a multi-institutional analysis. Ann Surg 2005;242(03):422-428

40 Okada A, Usui N, Inoue M, et al. Esophageal atresia in Osaka: a review of 39 years' experience. J Pediatr Surg 1997;32(11): 1570-1574

41 Wayson EE, Garnjobst W, Chandler JJ, Peterson CG. Esophageal atresia with tracheoesophageal fistula; Lessons of a quarter century's experience. Am J Surg 1965;110:162-167

42 Strodel WE, Coran AG, Kirsh MM, Weintraub WH, Wesley JR, Sloan H. Esophageal atresia. A 41-year experience. Arch Surg 1979;114(04):523-527

43 Little DC, Rescorla FJ, Grosfeld JL, West KW, Scherer LR, Engum SA. Long-term analysis of children with esophageal atresia and tracheoesophageal fistula. J Pediatr Surg 2003;38(06):852-856

44 Schier F, Korn S, Michel E. Experiences of a parent support group with the long-term consequences of esophageal atresia. J Pediatr Surg 2001;36(04):605-610

45 Rokitansky AM, Kolankaya VA, Seidl S, et al. Recent evaluation of prognostic risk factors in esophageal atresia-a multicenter review of 223 cases. Eur J Pediatr Surg 1993;3(04):196-201 
46 Huang J, Tao J, Chen K, et al. Thoracoscopic repair of oesophageal atresia: experience of 33 patients from two tertiary referral centres. J Pediatr Surg 2012;47(12):2224-2227

47 Oddsberg J, Lu Y, Lagergren J. Aspects of esophageal atresia in a population-based setting: incidence, mortality, and cancer risk. Pediatr Surg Int 2012;28(03):249-257

48 Sulkowski JP, Cooper JN, Lopez JJ, et al. Morbidity and mortality in patients with esophageal atresia. Surgery 2014;156(02): 483-491

49 Ein SH, Theman TE. A comparison of the results of primary repair of esophageal atresia with tracheoesophageal fistulas using endto-side and end-to-end anastomoses. J Pediatr Surg 1973;8(05): 641-645

50 Spoel M, Meeussen CJHM, Gischler SJ, et al. Respiratory morbidity and growth after open thoracotomy or thoracoscopic repair of esophageal atresia. J Pediatr Surg 2012;47(11):1975-1983

51 Koga H, Yamoto M, Okazaki T, et al. Factors affecting postoperative respiratory tract function in type-C esophageal atresia. Thoracoscopic versus open repair. Pediatr Surg Int 2014;30(12): 1273-1277

52 Dunkley ME, Zalewska KM, Shi E, Stalewski H. Management of esophageal atresia and tracheoesophageal fistula in North Queensland. Int Surg 2014;99(03):276-279

53 Donoso F, Lilja HE. Risk factors for anastomotic strictures after esophageal atresia repair: prophylactic proton pump inhibitors do not reduce the incidence of strictures. Eur J Pediatr Surg 2017; 27(01):50-55

54 Tröbs RB, Finke W, Bahr M, et al. Isolated tracheoesophageal fistula versus esophageal atresia - early morbidity and shortterm outcome. A single institution series. Int J Pediatr Otorhinolaryngol 2017;94:104-111

55 Bakal U, Ersoz F, Eker I, Sarac M, Aydin M, Kazez A. Long-term prognosis of patients with esophageal atresia and/or tracheoesophageal fistula. Indian J Pediatr 2016;83(05):401-404

56 Bradshaw CJ, Thakkar H, Knutzen L, et al. Accuracy of prenatal detection of tracheoesophageal fistula and oesophageal atresia. J Pediatr Surg 2016;51(08):1268-1272

57 Donoso F, Kassa A-M, Gustafson E, Meurling S, Lilja HE. Outcome and management in infants with esophageal atresia - a single centre observational study. J Pediatr Surg 2016;51(09): 1421-1425

58 Hartley MJ, Smith NPM, Jaffray B. Statistical modelling of survival for babies with oesophageal atresia. J Pediatr Surg 2016;51(07): $1110-1114$

59 Okata Y, Maeda K, Bitoh Y, et al. Evaluation of the intraoperative risk factors for esophageal anastomotic complications after primary repair of esophageal atresia with tracheoesophageal fistula. Pediatr Surg Int 2016;32(09):869-873

60 Tong S, Mallitt K-A, Krishnan U. Evaluation of gastroesophageal reflux by combined multichannel intraluminal impedance and $\mathrm{pH}$ monitoring and esophageal motility patterns in children with esophageal atresia. Eur J Pediatr Surg 2016;26(04):322-331

61 Uygun I, Zeytun H, Otcu S. Immediate primary anastomosis for isolated oesophageal atresia: a single-centre experience. Afr J Paediatr Surg 2015;12(04):273-279

62 Fallon SC, Ethun CG, Olutoye OO, et al. Comparing characteristics and outcomes in infants with prenatal and postnatal diagnosis of esophageal atresia. J Surg Res 2014;190(01):242-245

63 Lee S, Lee S-K, Seo J-M. Thoracoscopic repair of esophageal atresia with tracheoesophageal fistula: overcoming the learning curve. J Pediatr Surg 2014;49(11):1570-1572

64 Niramis R, Tangkhabuanbut P, Anuntkosol M, Buranakitjaroen V, Tongsin A, Mahatharadol V. Clinical outcomes of esophageal atresia: comparison between the Waterston and the Spitz classifications. Ann Acad Med Singapore 2013;42(06):297-300

65 Sfeir R, Michaud L, Salleron J, Gottrand F. Epidemiology of esophageal atresia. Dis Esophagus 2013;26(04):354-355
66 Jawaid W, Chan B, Jesudason EC. Subspecialization may improve an esophageal atresia service but has not addressed declining trainee experience. J Pediatr Surg 2012;47(07):1363-1368

67 Burford JM, Dassinger MS, Copeland DR, Keller JE, Smith SD. Repair of esophageal atresia with tracheoesophageal fistula via thoracotomy: a contemporary series. Am J Surg 2011;202(02): 203-206

68 Sistonen SJ, Pakarinen MP, Rintala RJ. Long-term results of esophageal atresia: Helsinki experience and review of literature. Pediatr Surg Int 2011;27(11):1141-1149

69 Zhao R, Li K, Shen C, Zheng S. The outcome of conservative treatment for anastomotic leakage after surgical repair of esophageal atresia. J Pediatr Surg 2011;46(12):2274-2278

70 de Jong EM, de Haan MAM, Gischler SJ, et al. Pre- and postnatal diagnosis and outcome of fetuses and neonates with esophageal atresia and tracheoesophageal fistula. Prenat Diagn 2010;30 (03):274-279

71 Serhal L, Gottrand F, Sfeir R, et al. Anastomotic stricture after surgical repair of esophageal atresia: frequency, risk factors, and efficacy of esophageal bougie dilatations. J Pediatr Surg 2010;45 (07):1459-1462

72 MacKinlay GA. Esophageal atresia surgery in the 21st century. Semin Pediatr Surg 2009;18(01):20-22

73 Patkowsk D, Rysiakiewicz K, Jaworski W, et al. Thoracoscopic repair of tracheoesophageal fistula and esophageal atresia. J Laparoendosc Adv Surg Tech A 2009;19(Suppl 1):S19-S22

74 Tandon RK, Khan TR, Maletha M, Rawat JD, Wakhlu A, Kureel SN. Modified method of primary esophageal anastomosis with improved outcome in cases of esophageal atresia with tracheoesophageal fistula. Pediatr Surg Int 2009;25(04):369-372

75 Sri Paran T, Decaluwe D, Corbally M, Puri P. Long-term results of delayed primary anastomosis for pure oesophageal atresia: a 27year follow up. Pediatr Surg Int 2007;23(07):647-651

76 van der Zee DC, Bax KNMA. Thoracoscopic treatment of esophageal atresia with distal fistula and of tracheomalacia. Semin Pediatr Surg 2007;16(04):224-230

77 Uchida K, Inoue M, Otake K, et al. Efficacy of postoperative elective ventilatory support for leakage protection in primary anastomosis of congenital esophageal atresia. Pediatr Surg Int 2006;22(06):496-499

78 Al-Malki TA, Ibrahim AH. Esophageal atresia with tracheoesophageal fistula and early postoperative mortality. West Afr J Med 2005;24(04):311-315

79 Calisti A, Oriolo L, Nanni L, Molle P, Briganti V, D’Urzo C. Mortality and long term morbidity in esophageal atresia: the reduced impact of low birth weight and maturity on surgical outcome. J Perinat Med 2004;32(02):171-175

80 Deurloo JA, Smit BJ, Ekkelkamp S, Aronson DC. Oesophageal atresia in premature infants: an analysis of morbidity and mortality over a period of 20 years. Acta Paediatr 2004;93 (03):394-399

81 Orford J, Cass DT, Glasson MJ. Advances in the treatment of oesophageal atresia over three decades: the 1970s and the 1990s. Pediatr Surg Int 2004;20(06):402-407

82 Tönz M, Köhli S, Kaiser G. Oesophageal atresia: what has changed in the last 3 decades? Pediatr Surg Int 2004;20(10):768-772

83 Touloukian RJ, Seashore JH. Thirty-five-year institutional experience with end-to-side repair for esophageal atresia. Arch Surg 2004;139(04):371-374

84 Konkin DE, O'hali WA, Webber EM, Blair GK. Outcomes in esophageal atresia and tracheoesophageal fistula. J Pediatr Surg 2003;38(12):1726-1729

85 van der Zee DC, Bax NMA. Thoracoscopic repair of esophageal atresia with distal fistula. Surg Endosc 2003;17(07):1065-1067

86 Deurloo JA, Ekkelkamp S, Schoorl M, Heij HA, Aronson DC. Esophageal atresia: historical evolution of management and results in 371 patients. Ann Thorac Surg 2002;73(01):267-272 
87 Sparey C, Jawaheer G, Barrett AM, Robson SC. Esophageal atresia in the Northern Region Congenital Anomaly Survey, 1985-1997: prenatal diagnosis and outcome. Am J Obstet Gynecol 2000;182 (02):427-431

88 Nawaz A, Matta H, Shawis R, Jazcobsz A, Kassir S, Al-Salem AH. Esophageal atresia and tracheoesophageal fistula: success and failure rates in the United Arab Emirates. Pediatr Surg Int 1998; 14(03):214-217

89 Somppi E, Tammela O, Ruuska T, et al. Outcome of patients operated on for esophageal atresia: 30 years' experience. J Pediatr Surg 1998;33(09):1341-1346

90 Tsai JY, Berkery L, Wesson DE, Redo SF, Spigland NA. Esophageal atresia and tracheoesophageal fistula: surgical experience over two decades. Ann Thorac Surg 1997;64(03):778-783

91 Engum SA, Grosfeld JL, West KW, Rescorla FJ, Scherer LR III. Analysis of morbidity and mortality in 227 cases of esophageal atresia and/or tracheoesophageal fistula over two decades. Arch Surg 1995;130(05):502-508, discussion 508-509

92 Rokitansky A, Kolankaya A, Bichler B, Mayr J, Menardi G. Analysis of 309 cases of esophageal atresia for associated congenital malformations. Am J Perinatol 1994;11(02):123-128

93 Alexander F, Johanningman J, Martin LW. Staged repair improves outcome of high-risk premature infants with esophageal atresia and tracheoesophageal fistula. J Pediatr Surg 1993;28(02): 151-154

94 Touloukian RJ. Reassessment of the end-to-side operation for esophageal atresia with distal tracheoesophageal fistula: 22year experience with 68 cases. J Pediatr Surg 1992;27(05): 562-567

95 Poenaru D, Laberge JM, Neilson IR, Nguyen LT, Guttman FM. A more than 25-year experience with end-to-end versus end-toside repair for esophageal atresia. J Pediatr Surg 1991;26(04): 472-476

96 McKinnon LJ, Kosloske AM. Prediction and prevention of anastomotic complications of esophageal atresia and tracheoesophageal fistula. J Pediatr Surg 1990;25(07):778-781

97 Adebo OA. Oesophageal atresia and tracheo-oesophageal fistula: review of a 10-year personal experience. West Afr J Med 1990;9 (03):164-169

98 Chittmittrapap S, Spitz L, Kiely EM, Brereton RJ. Anastomotic stricture following repair of esophageal atresia. J Pediatr Surg 1990;25(05):508-511

99 Randolph JG, Newman KD, Anderson KD. Current results in repair of esophageal atresia with tracheoesophageal fistula using physiologic status as a guide to therapy. Ann Surg 1989;209(05): 526-530

100 Pohlson EC, Schaller RT, Tapper D. Improved survival with primary anastomosis in the low birth weight neonate with esophageal atresia and tracheoesophageal fistula. J Pediatr Surg 1988;23(05):418-421

101 Sillén U, Hagberg S, Rubenson A, Werkmäster K. Management of esophageal atresia: review of 16 years' experience. J Pediatr Surg 1988;23(09):805-809

102 Biller JA, Allen JL, Schuster SR, Treves ST, Winter HS. Long-term evaluation of esophageal and pulmonary function in patients with repaired esophageal atresia and tracheoesophageal fistula. Dig Dis Sci 1987;32(09):985-990

103 Connolly B, Guiney EJ. Trends in tracheoesophageal fistula. Surg Gynecol Obstet 1987;164(04):308-312

104 Spitz L, Kiely E, Brereton RJ. Esophageal atresia: five year experience with 148 cases. J Pediatr Surg 1987;22(02):103-108

105 Bishop PJ, Klein MD, Philippart AI, Hixson DS, Hertzler JH. Transpleural repair of esophageal atresia without a primary gastrostomy: 240 patients treated between 1951 and 1983 . J Pediatr Surg 1985;20(06):823-828
106 Louhimo I, Lindahl H. Esophageal atresia: primary results of 500 consecutively treated patients. J Pediatr Surg 1983;18(03): 217-229

107 O'Neill JA Jr, Holcomb GW Jr, Neblett WW III. Recent experience with esophageal atresia. Ann Surg 1982;195(06):739-745

108 Lindahl H, Louhimo I, Virkola K. 30-year follow-up of the original Sulamaa (end-to-side) operation for oesophageal atresia. Z Kinderchir 1983;38(03):152-154

109 Touloukian RJ. Long-term results following repair of esophageal atresia by end-to-side anastomosis and ligation of the tracheoesophageal fistula. J Pediatr Surg 1981;16(06):983-988

110 Atwell JD, Harrison GS. Observations on the role of esophagogastrostomy in infancy and childhood with particular reference to the long-term results and operative mortality. J Pediatr Surg 1980;15(03):303-309

111 Hrabovsky E, Boles ET Jr. Long term results following esophageal anastomosis in the neonate. Surg Gynecol Obstet 1978;147(01): 30-32

112 Fasting H, Winther LK. Oesophageal atresia and tracheo-oesophageal fistula. Early and late results in 86 patients. Scand J Thorac Cardiovasc Surg 1978;12(02):147-151

113 Pietsch JB, Stokes KB, Beardmore HE. Esophageal atresia with tracheoesophageal fistula: end-to-end versus end-to-side repair. J Pediatr Surg 1978;13(6D):677-681

114 Exarhos ND, Moutsouris C, Skalkeas G. Esophageal atresia with tracheoesophageal fistula. Int Surg 1977;62(04):202-203

115 Orringer MB, Kirsh MM, Sloan H. Long-term esophageal function following repair of esophageal atresia. Ann Surg 1977;186(04): 436-443

116 Laks H, Wilkinson RH, Schuster SR. Long-term results following correction of esophageal atresia with tracheoesophageal fistula: a clinical and cinefluorographic study. J Pediatr Surg 1972;7(05): 591-597

117 Battersby JS, Jolly WW, Fess SW. Esophageal atresia: a comprehensive study of 210 patients. Bull Soc Int Chir 1971;30(05): 415-420

118 Ferguson CC. Management of infants with esophageal atresia and tracheoesophageal fistula. Ann Surg 1970;172(04):750-754

119 Holden MP, Wooler GH. Tracheo-oesophageal fistula and oesophageal atresia: results of 30 years' experience. Thorax 1970;25 (04):406-412

120 Krishinger GL, Woolley MM. Esophageal atresia and tracheoesophageal fistula. 25 years' experience and current management. Calif Med 1969;111(03):165-168

121 Romsdahl MM, Hunter JA, Grove WJ. Tracheoesophageal fistula and esophageal atresia. Surgical management and results at a university hospital. J Thorac Cardiovasc Surg 1966;52(04):571-578

122 Waterston DJ, Carter RE, Aberdeen E. Oesophageal atresia: tracheo-oesophageal fistula. A study of survival in 218 infants. Lancet 1962;1(7234):819-822

123 Hays DM. An analysis of the mortality in esophageal atresia. Am J Dis Child 1962;103:765-770

124 Rehbein F, Yanagiswa F. Complications after operation for oesophageal atresia. Arch Dis Child 1959;34(173):24-29

125 Ashe WM, Seybold WD. Congenital atresia of the esophagus with tracheo-esophageal fistula treated by primary esophageal anastomosis; report of eight cases. Proc Staff Meet Mayo Clin 1949; 24(12):327-333

126 Ladd WE, Swenson O. Esophageal atresia and tracheo-esophageal fistula. Ann Surg 1947;125(01):23-40

127 Daniel RA. Congenital atresia of the esophagus: with tracheoesophageal fistula. Ann Surg 1944;120(05):764-771

128 Haight C. Congenital atresia of the esophagus with tracheoesophageal fistula: reconstruction of esophageal continuity by primary anastomosis. Ann Surg 1944;120(04):623-652 